www.amlett.com, www.amlett.org, DOI: 10.5185/amlett.2012.ib.107

"Nanostructuring by electrons, photons and ions" Special Issue Published online by the VBRI press in 2013

\title{
Effect of swift heavy ion on structural and optical properties of undoped and doped nanocrystalline zinc oxide films
}

\author{
Vinod Kumar $^{1^{*}}$, R. G. Singh ${ }^{2}$, L. P. Purohit ${ }^{3}$, Fouran Singh ${ }^{1}$ \\ ${ }^{1}$ Materials Science Group, Inter University Accelerator Centre, Aruna Asaf Ali Marg New Delhi 110 067, India \\ ${ }^{2}$ Department of Electronic Science, Maharaja Agrasen College University of Delhi 110 096, India \\ ${ }^{3}$ Department of Physics, Gurukula Kangri University, Haridwar 249 404, India
}

*Corresponding author. E-mail: vinod.phy@gmail.com

Received: 16 March 2012, Revised: 22 July 2012 and Accepted: 26 July 2012

\section{ABSTRACT}

Swift heavy ion (SHI) induced modification in structural and optical properties of undoped and doped nanocrystalline (nc) ZnO films deposited by sol-gel method are investigated. These nanocrystalline films were irradiated by $\mathrm{MeV}$ ions of $\mathrm{Au}, \mathrm{Ag}$ and $\mathrm{Ni}$ at various ion fluences. The structural properties were studied using X-ray diffraction and it shows that the average crystallite size of $\mathrm{ZnO}$ films is observed to increase by the irradiation. The atomic force microscopy (AFM) study of films shows that the roughness of the films varies with increase in the fluence. A maximum transmittance is observed to be $85 \%$ in the visible region for doped films. It is also shown that the bandgap of undoped and doped $\mathrm{ZnO}$ films is varied using SHI irradiation. The modifications of structural and optical properties are explained in terms of thermal spikes induced by SHIs. Copyright $@ 2013$ VBRI press.

Keywords: nc-ZnO; swift heavy ion; sol-gel; band gap narrowing and widening; $\mathrm{ZnO}: \mathrm{B}$
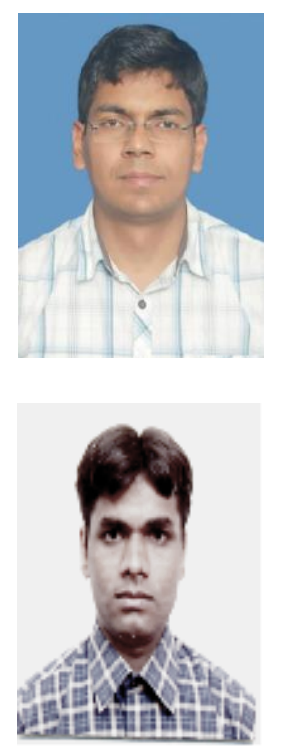

Vinod Kumar is a Research Associate in Inter University Accelerator Centre, New Delhi, India. $\mathrm{He}$ has completed his Ph.D. from Gurukula Kangri University, Uttarakhand, India in 2011. $\mathrm{He}$ is involved in research work of metal oxide based nano-devices and the role of Swift Heavy Ion in nano-devices. He has published more than 15 research papers in journals of international repute. He has presented his work in several international and national conferences as well.

Ram Gopal Singh did doctorate from University of Delhi and presently working as Assistant Professor in University of Delhi at Maharaja Agrasen College. I have authored/co-authored of 15 research articles in reputed International refereed Journals. The published articles are well recognized by the scientific research community. My current research interests are in the development of Hybrid nanocomposites, NanoDimensional Metal Oxide Semiconductor and Role of Swift Heavy Ion in Hybrid Nanocomposites and nanostructures of Metal Oxide Semiconductor. I have recently developed device which is based on Hybrid nanocomposites such as Solid State Dye Sensitized Solar Cell, Photodiode and LEDs (Hybrid Photonics).

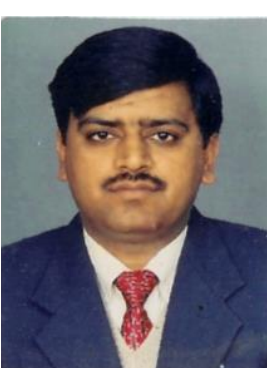

L. P. Purohit is working as an Associate Professor in Department of Physics, Gurukula Kangri University, Haridwar (India). Major Fields of research are Amorphous Semiconductor Materials, II-VI Semiconductors and Magnetic Materials. Seven scholars were awarded Ph.D. degree under his direct supervision. He is teaching Quantum Mechanics and Applied Electronics at Post graduate level. He has more than 35 research papers published in international refereed journals. Delivered invited talks and chaired the technical sessions in national and international conferences. He is the member of Board of studies and Research Degree committees of different Universities. About 20 years of experience in teaching \& research in Physics.

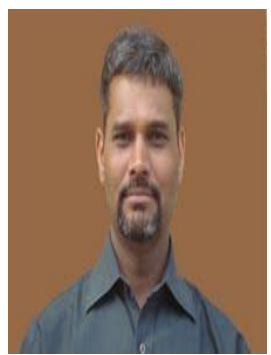

Fouran Singh did doctorate from University of Paris south XI, Orsay campus and presently working as Sr. Scientist at Inter University Accelerator Centre (IUAC), New Delhi. I have authored/co-authored more than $150+$ research articles in reputed International refereed Journals. The published articles are well recognized by the research community, as it is clear from Scopus citation history (h-index 19, i10-index 42). My current research interests are in the development of nanocomposites, nanostructures, nanophosphors and thin films for optoelectronic, display and photovoltaic devices. 


\section{Introduction}

Zinc Oxide $(\mathrm{ZnO})$ is II-VI compound semiconductor with hexagonal wurtzite structure. $\mathrm{ZnO}$ has a direct band gap of about $3.37 \mathrm{eV}$ [1] and large exciton binding energy of 60 $\mathrm{meV}$ at room temperature [2]. Annealing [3], doping [4] and irradiation [5-8] can tune the properties of $\mathrm{ZnO}$ film. $\mathrm{ZnO}$ have attracted much attention and research activities in view of their potential application such as light emitting diode [9], spintronic device [10], transparent conductive electrodes $[4,11]$, laser $[\mathbf{1 2}]$ and solar cells $[\mathbf{1 3}, \mathbf{1 4}]$. Effect of boron doping on the properties of the transition is explained by the defects induced disorder and strain in $\mathrm{ZnO}$ crystallites created by high density of electronic excitations. $\mathrm{ZnO}$ film is reported by different preparation techniques [15-17]. Recently, Xu et. al have reported that boron doped $\mathrm{ZnO}$ are very useful material for a magnetic application [18].

The defects in $\mathrm{ZnO}$ can be altered by various treatments like thermal annealing in controlled environment or by ion beam irradiations. It is known that the thin films of $\mathrm{ZnO}$ cannot be amorphized by ion irradiations [19]. SHI irradiation is a unique technique to modify structural, optical, opto-electronic and transport properties of materials [20, 21]. When SHI penetrate a solid, it slows down via two processes of direct transfer of energy to target atoms through elastic collisions i.e. nuclear energy loss $\left(\mathrm{S}_{\mathrm{n}}\right)$, or electronic excitation and ionization of target atoms by inelastic collision i.e. electronic energy loss $\left(S_{e}\right)$. The second process is predominant in case of SHI irradiation. It supplies huge excitations $\left(\mathrm{S}_{\mathrm{e}}\right)$ as compared to that produced by elastic collisions $\left(\mathrm{S}_{\mathrm{n}}\right)$, if the thickness of target is much smaller as compared to the range $(\sim 9 \mu \mathrm{m})$ of the projectile ions. SHI modifies the properties by two processes of: (i) controlling the type and density of defects [22], and (ii) by creating the stress and strain in the structure [23]. This technique presents the advantage of permitting to control the amount of energy to the system through the ion mass, energy, and fluence, and it is much localized in narrow cylinder along the ion path known as ion tracks. Therefore, the process of heavy ion irradiation can be used to understand and control the evolution kinetics of phonon structures in the nanocrystalline materials. Many groups have reported effect of irradiation on $\mathrm{ZnO}$ films [6-9, 1923], but to the best of our knowledge there is no work is on the SHI irradiation of boron doped $\mathrm{ZnO}$ film. Therefore, present work reports the SHI irradiation induced modification in the structural and optical properties of the sol-gel grown undoped and boron doped $\mathrm{ZnO}$ thin films.

\section{Experimental}

Undoped and boron doped $\mathrm{ZnO}$ ( $\mathrm{ZnO}$ and $\mathrm{ZnO}: \mathrm{B}$ ) films were successfully grown on corning (1737) glass substrate by sol-gel method using spin coating technique. Zinc acetate dihydrate (Merck) was used as starting material. Methanol (AR, Merck) and Monoethanolamine (Merck) were used as the solvent and stabilizer, respectively. The zinc precursor solution was prepared by dissolving zinc acetate dehydrate in methanol so as prepare concentration of $0.2 \mathrm{~mol} / \mathrm{l}$. The molar ratio MEA/Zn was fixed to 1 for all samples. Trimethyl borate is dissolved in the solution and concentration of boron is fixed 0.6 at.\%. The doping concentration of boron in $\mathrm{ZnO}$ : $\mathrm{B}$ film was optimizing in our previous work [4]. The mixture solution was stirred by using a magnetic stirrer at $25^{\circ} \mathrm{C}$ for $2 \mathrm{~h}$. The clear transparent and homogenous solution thus obtained was left to age for $72 \mathrm{~h}$. Substrate was cleaned ultrasonically, first in acetone and then subsequently in methanol for ten minutes each. They were further cleaned with deionized water for $20 \mathrm{~min}$. One drop of solution was drop onto substrate, which were rotated at $2500 \mathrm{rpm}$ for $30 \mathrm{sec}$ by a spin coating unit. After deposition, films were dried in air at $230^{\circ} \mathrm{C}$ for $10 \mathrm{~min}$ over hot plate to evaporate the solvent and remove organic residuals. The process from coating to drying has been repeated for fifteen times to obtain the desired thickness of the films. The film thickness is observed into be approximately $280 \mathrm{~nm}$. The films were inserted to a microprocessor controlled furnace and annealed in air at $450^{\circ} \mathrm{C}$ temperature for $1 \mathrm{~h}$ heating rate of furnace is fixed $5 \%$ min.

The annealed films were irradiated with $120 \mathrm{MeV} \mathrm{Ag}^{+9}$, $50 \mathrm{MeV} \mathrm{Ni}$ and $120 \mathrm{MeV} \mathrm{Au+9}$ ions using the 15UD Pelletron Accelerator facility at Inter University Accelerator Centre (IUAC), New Delhi. Electronic energy loss $\left(\mathrm{S}_{\mathrm{e}}\right)$ of $\mathrm{Ag}, \mathrm{Ni}$ and $\mathrm{Au}$ ions in the $\mathrm{ZnO}$ is 21.67 $\mathrm{KeV} / \mathrm{nm}, 12.65 \mathrm{KeV} / \mathrm{nm}$ and $24.63 \mathrm{KeV} / \mathrm{nm}$, while nuclear energy loss $\left(\mathrm{S}_{\mathrm{n}}\right)$ is $0.105,0.049 \mathrm{KeV} / \mathrm{nm}$ and 0.044 $\mathrm{KeV} / \mathrm{nm}$ as estimated from SRIM simulations [24]. The focused ion beam was scanned over an area of $1 \mathrm{~cm}^{2}$ with the fluences of $1 \times 10^{11}$ to $3 \times 10^{13}$ ions $/ \mathrm{cm}^{2}$ and the beam current was kept constant 1 pnA (particles nanoampere). The modifications of the properties are expected mainly due to the electronic excitation induced by SHI, as the range of the ions is much larger than the film thickness. Crystalline nature of the $\mathrm{ZnO}$ films was confirmed by PAN alytical X'pert PRO diffractometer using the $\mathrm{CuK}_{\alpha}$ radiation having a wavelength of $1.5140^{\circ} \mathrm{A}$. The film thickness was measured by surface profiler ambious XP-1. The band gap of $\mathrm{ZnO}$ films were measured by optical transmittance using a Shimadzu Solid Spec 3700 double beam spectrophotometer.

\section{Results and discussion}

\section{Structural analysis of $\mathrm{ZnO}$ and $\mathrm{ZnO}: \mathrm{B}$ films}

Fig. 1 shows X-ray diffraction (XRD) pattern of $\mathrm{ZnO}$ and $\mathrm{ZnO}: \mathrm{B}$ films annealed at $450^{\circ} \mathrm{C}$ temperatures with different fluence. A strong diffraction peak (002) of $\mathrm{ZnO}$ with hexagonal wurtzite crystal structure (JCPDS card No. 790206) is observed in pristine and irradiated films. It indicates that most of the grains in $\mathrm{ZnO}$ and $\mathrm{ZnO}: \mathrm{B}$ have a strong orientation along $c$-axis (002) plane as reported in JCPDS card No. 79-0206. The peak intensity of $\mathrm{ZnO}$ and $\mathrm{ZnO}: \mathrm{B}$ is changed after irradiation. The transfer of energy from the ion to the target is mainly due to electronic energy loss. According to thermal spike model [25] this transfer of very large amount of energy to the target is responsible for the formation of very high temperature zones along the ion paths formed by SHI during irradiation. This results in the melting of $\mathrm{ZnO}$ and other impurity phases if present, to form a homogeneous mixture followed by rapid thermal quenching in the range of $10^{12}-10^{14} \mathrm{~K} / \mathrm{s}$. The formations of removal of defects, structural strain and order/disordering thus produced in this process is responsible for the 
modifications in structural and other properties in various materials. Crystallite size of the $\mathrm{ZnO}$ and $\mathrm{ZnO}: \mathrm{B}$ has been calculated using XRD data [26]

$$
d=\frac{k \lambda}{\beta \cos \theta}
$$

where, $\mathrm{k}$ is correction factor $(0.94), \lambda$ is $\mathrm{X}$-ray wavelength $\left(1.5406^{\circ} \mathrm{A}\right), \beta$ is the full width half maximum and $\theta$ is Bragg diffraction angle. The crystallite size of $\mathrm{ZnO}$ is observed $25 \pm 0.6$ and $32 \pm 1.0 \mathrm{~nm}$ for pristine and irradiated films. The crystallite size is increased from $17 \pm 0.5$ to $52 \pm 1.0 \mathrm{~nm}$ with increase fluences in $\mathrm{ZnO}: \mathrm{B}$ films.
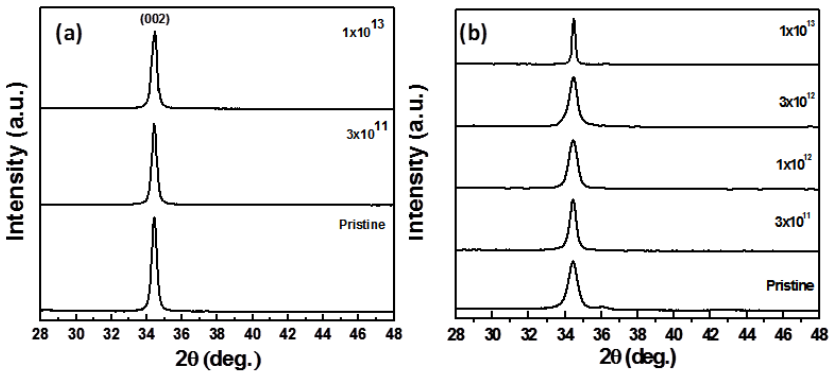

Fig. 1. (a) X-ray diffraction pattern of pristine and irradiated $\mathrm{ZnO}$ films at different ion fluencies and (b) X-ray diffraction pattern of pristine and irradiated $\mathrm{ZnO}: \mathrm{B}$ films at different ion fluencies.

\section{Effect of different $S_{e}$ on as-deposited pure ZnO films}

The effect of energy loss on the growth of $\mathrm{ZnO}$ crystallites is studied by performing irradiation experiments using 50 $\mathrm{MeV} \mathrm{Ni}$ and $120 \mathrm{MeV} \mathrm{Au}$ ions on undoped as-deposited $\mathrm{ZnO}$ films. The ion and their energy are chosen such that $\mathrm{Au}$ is having $\mathrm{S}_{\mathrm{e}}$ almost by a factor of 2 larger in $\mathrm{ZnO}$ crystallites as compared to $\mathrm{Ni}$. XRD patterns of the asdeposited, $\mathrm{Ni}$ irradiated and $\mathrm{Au}$ irradiated $\mathrm{ZnO}$ films at $1 \times 10^{13}$ ion $/ \mathrm{cm}^{2}$ fluences are shown in Fig. 2 . The diffraction peaks appear at $31.8,34.4$ and $36.3^{\circ}$, which correspond to (100), (002) and (101) planes respectively of hexagonal wurtzite $\mathrm{ZnO}$. The crystallite size is calculated by Debye-Scherer formula [26] and it is obtained to be $5.4 \pm 0.4,6.3 \pm 0.5$ and $10.6 \pm 0.5 \mathrm{~nm}$ for as-deposited, $\mathrm{Ni}$ irradiated and $\mathrm{Au}$ irradiated films respectively. The increase in the crystallite size for $\mathrm{Ni}$ irradiated film is about $16 \%$; while it is about $96 \%$ for $\mathrm{Au}$ irradiated film. This variation in the growth of the crystallites for $\mathrm{Ni}$ and $\mathrm{Au}$ irradiation could be ascribed to the difference in the electronic stopping power. However, from the present experiment it is clear that the rate of the growth of crystallites strongly depends on the electronic stopping power, but the exact dependence of the growth of the crystallites on electronic stopping power and the role of the nuclear stopping power in this domain could not be determined from the presented preliminary data. The lattice constant ' $c$ ' of $\mathrm{ZnO}$ film is also calculated from the diffraction pattern and obtained to be 5.22, 5.23 and 5.19 ${ }^{\circ} \mathrm{A}$ for as-deposited, Ni irradiated and $\mathrm{Au}$ irradiated film; respectively. The variation in the lattice constant of the $\mathrm{Ni}$ irradiated film is almost same, while there is a significant decrease for $\mathrm{Au}$ irradiated $\mathrm{ZnO}$ film. Such kind of decrease in the lattice constant is reported by Singh et al $[6,8]$ and is attributed to the stress in the crystallites induced by high density of defects created by huge electronic stopping power of $\mathrm{Au}$.

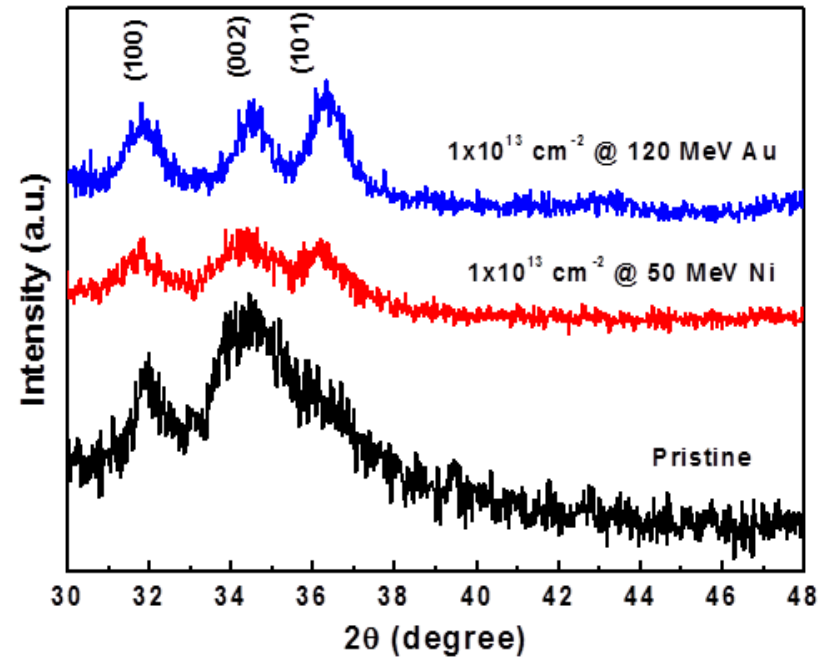

Fig. 2. X-ray diffraction pattern of As-deposited and $\mathrm{Ni}$ or Au irradiated $\mathrm{ZnO}$ film.

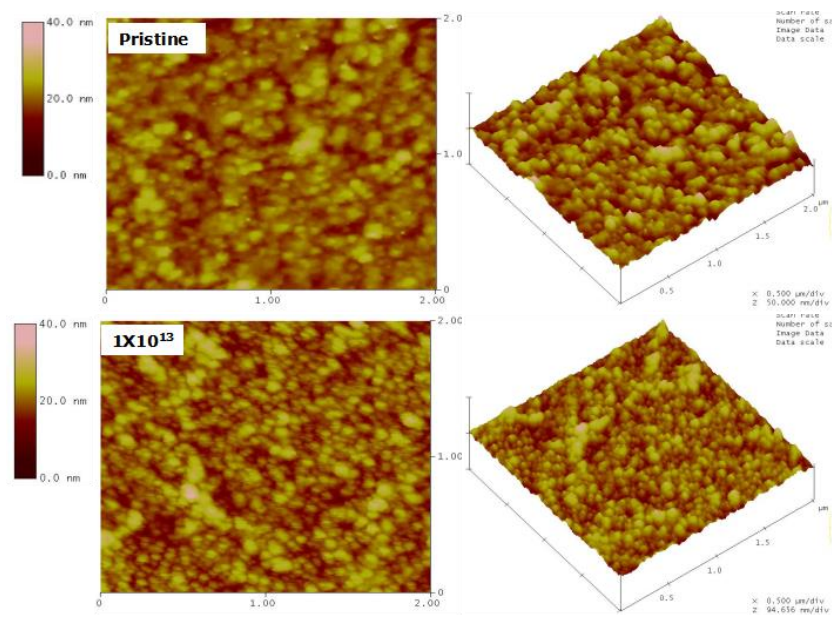

Fig. 3. AFM micrographs of pristine and irradiated $\mathrm{ZnO}$ films.

\section{Surface morphology of $\mathrm{ZnO}$ and $\mathrm{ZnO}: \mathrm{B}$ films}

The surface topography of the pristine and irradiated $\mathrm{ZnO}$ and $\mathrm{ZnO}: \mathrm{B}$ films were studied using Atomic Force Microscopy (AFM) in the tapping mode. Fig. 3 shows the two and three dimensional micrograph in $2 \times 2 \mu \mathrm{m}^{2}$ of $\mathrm{ZnO}$ films. The root mean square (rms) roughness of $\mathrm{ZnO}$ films was decreased from 3.97 to $3.22 \mathrm{~nm}$ after irradiation. The grain size of $\mathrm{ZnO}$ film is decreased from 86 to $39 \mathrm{~nm}$ after irradiation. The energetic heavy ions provide sufficient energy for promoting the sputtering from the surface of the grains that leads to reduction in the grain size of $\mathrm{ZnO}$ films. Fig. 4 shows the two and three dimensional micrograph in $2 \times 2 \mu^{2}$ of $\mathrm{ZnO}: \mathrm{B}$ films. In $\mathrm{ZnO}: \mathrm{B}$ films roughness is increased from 2.17 to $10.38 \mathrm{~nm}$ after irradiation. The grain size of $\mathrm{ZnO}: \mathrm{B}$ film is increased from 47 to $82 \mathrm{~nm}$ after irradiation. Such drastic change in the size and shape of the grains at higher fluence is attributed to the high density of 
electronic excitations induced by SHI irradiation under multiple ion impacts in the near surface region [27]. Kumaravel et.al [28] has also reported increased in grain size with increase in roughness of films due to the increase of density and size of metal particles on the surfaces of the films.

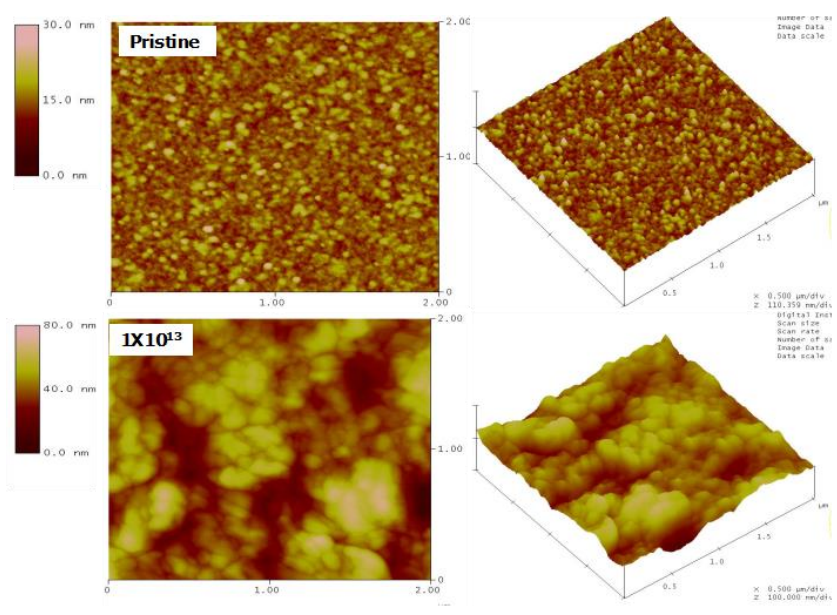

Fig. 4. AFM micrographs of pristine and irradiated $\mathrm{ZnO}$ :B films

\section{Optical properties of $\mathrm{ZnO}$ and $\mathrm{ZnO}: \mathrm{B}$ films}

Fig. 5 shows the influence of irradiation on the transmission of $\mathrm{ZnO}$ and $\mathrm{ZnO}: \mathrm{B}$ films. The average transmittance is increased with increase in fluences in $\mathrm{ZnO}$ film but it is decreased in $\mathrm{ZnO}: \mathrm{B}$ film due to the change in roughness of films. Pristine sample of $\mathrm{ZnO}$ had $65 \%$ transmittance in visible region and it is increased to $85 \%$. The increase in the transmittance of $\mathrm{ZnO}$ films after irradiation may be due to decrease optical scattering caused by decrease in the roughness of film (3.97 to $3.22 \mathrm{~nm}$ ) as demonstrated by the AFM images (Fig. 3). Singh et. al [29] have reported that the transmittance of indium tin oxide films is increased from 75 to $84 \%$ in visible region and the increase in transmittance is increased for electrode in Dye Sensitized Solar cell. However, pristine sample of $\mathrm{ZnO}: \mathrm{B}$ have obtained $91 \%$ transmittance in visible region and it is reduced to $85 \%$. The reduction in optical transmittance due to irradiation may be resulting from the increase in metal to oxygen ratio $(\mathrm{Zn} / \mathrm{O})$ in irradiated films, causing increase in carrier density. Kumar et. al [7] have also reported that the transmittance of $\mathrm{ZnO}$ films is decreased with fluence. In a direct band gap semiconductor, the absorption coefficient $\alpha$ is correlated to the optical band gap by this equation [30]-

$\alpha h v=A\left(h v-E_{g}\right)^{1 / 2}$

where, hv is photon energy, $A$ is constant and $E_{g}$ is the optical band gap. The band gap $\mathrm{E}_{\mathrm{g}}$ is determined by extrapolating of the linear part of the $\alpha^{2}$ curve towards the hv axis. The band gap of $\mathrm{ZnO}$ and $\mathrm{ZnO}: \mathrm{B}$ is shown in Fig. 6. The bandgap of $\mathrm{ZnO}$ is varied from 3.24 to $3.26 \mathrm{eV}$ with change in fluence. No much more change is observed in the band gap of $\mathrm{ZnO}$ after irradiation. Bandgap of $\mathrm{ZnO}: \mathrm{B}$ films is decreased at low influence but it is increase at higher influence. The band gap of $\mathrm{ZnO}: \mathrm{B}$ films is changed from
3.27 to $3.37 \mathrm{eV}$ with change in fluences. It has been established that in lower fluencies $\mathrm{ZnO}: \mathrm{B}$ film inclusion of band gap narrowing due to many body effects is necessary to account for the net shift in the band gap. Band gap of $\mathrm{ZnO}: \mathrm{B}$ is increased at higher fluence can be explained in term of Burstein-Moss (B-M) shift. Jain et al [31] reported the modification of band gap of $\mathrm{ZnO}$ due to the doping of $\mathrm{Al}, \mathrm{Y}$ and Sc and analyzed in terms of band gap narrowing and band gap widening phenomena. $\mathrm{ZnO}: \mathrm{B}$ is showing narrowing and widening in bandgap with vary in the fluences.
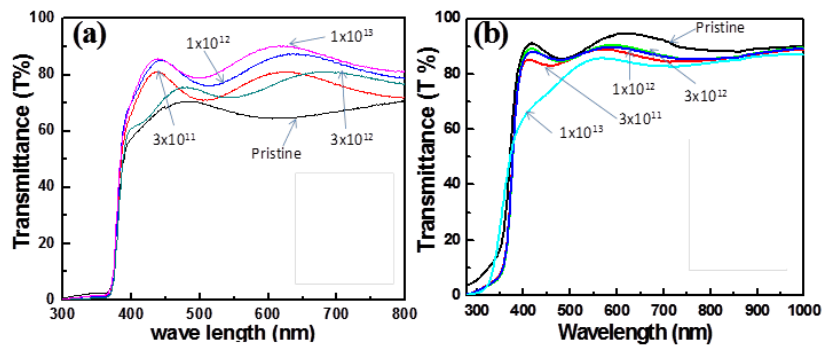

Fig. 5. Optical Transmittance spectra of pristine and irradiated $\mathrm{ZnO}$ and $\mathrm{ZnO}: \mathrm{B}$ films at different ion fluencies.
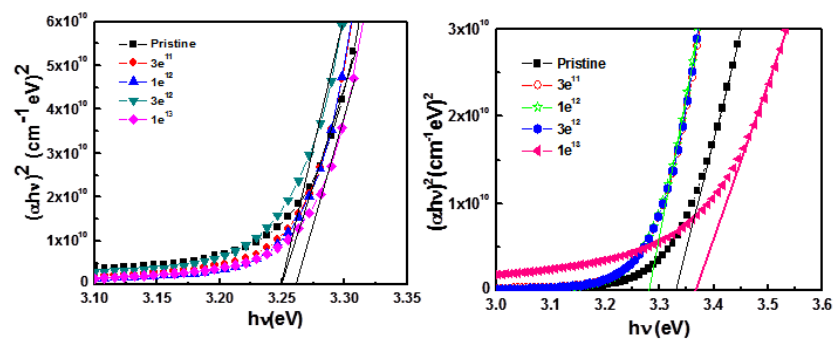

Fig. 6. Band gap variation of doped $\mathrm{ZnO}$ and $\mathrm{ZnO}: \mathrm{B}$ films with annealing temperature, calculated by Tauc's plot method.

\section{Conclusion}

We have investigated modifications of structural and optical properties of $\mathrm{ZnO}$ and $\mathrm{ZnO}: \mathrm{B}$ films with $120 \mathrm{MeV}$ $\mathrm{Ag}$ ion irradiation. We have observed the modifications of the intensity of XRD, surface morphology and Bandgap by ion irradiation. The transparency of $\mathrm{ZnO}$ and $\mathrm{ZnO}: \mathrm{B}$ is change after irradiation. Band gap narrowing and widening is observed in $\mathrm{ZnO}: \mathrm{B}$ with changed in ion flunce from $1 \times 10^{11}$ to $3 \times 10^{13}$ ion $/ \mathrm{cm}^{2}$. The observed modification in structural and optical properties was understood in the term of thermal spike model.

\footnotetext{
Acknowledgements

Authors are grateful to Dr. D. K. Avasthi for their encouragement and moral support. Authors are also acknowledges Prof. A. Kapoor UDSC for providing necessary facility. Authors are also grateful to Pelletron group for providing the stable beam during SHI irradiation experiment; and Mrs. I. Sulania for performing AFM measurements.

\section{Reference}

1. Yang, T. L.; Zhang, D. H.; Ma, J.; Ma H. L.; Chen, Y. Thin Solid Films 1998, 326, 60

2. Cordaro, J. F.; Shim, Y.; May, J. E. J. Appl. Phys. 1986, 60, 4186.

3. Singh, R. G.; Singh, Fouran; Kumar, Vinod; Mehra, R. M. Current Appl. Phys. 2011, 11, 624.
} 
4. Kumar, Vinod; Singh, R. G.; Purohit L. P., Mehra, R. M. J. Mater Sci. Technol. 2011, $27(6), 481$.

5. Singh, R. G.; Singh, Fouran; Sulania, I.; Kanjilal, D.; Sehrawat, K.; Agarwal, V.; Mehra, R. M. Nucl. Instr. and Meth. B 2009, 267, 2399.

6. Singh, Fouran; Singh, R. G.; Kumar, Vinod; Khan, S. A.; Pivin, J. C. J. Appl. Phys. 2011, 110, 083520.

7. Kumar, P. M. Ratheeesh; Kartha, C. Sudha; VijayaKumar, K. P.; Singh, F.; Avasthi, D. K.; Abe, T.; Kashiwaba, Y.; Okram, G. S.; Kumar M.; Kumar, Sarvesh J. Appl. Phys. 2005, 97, 013509.

8. Singh, Fouran; Kulriya P. K.; Pivin, J. C. Solid State Comm. 2010, $150,1751$.

9. Singh, R. G.; Singh, F.; Kanjilal, D.; Agarwal, V.; Mehra, R. M. J. Phys. D:Appl. Phys. 2009, 42, 062002.

10. Pivin, J. C.; Socol, G.; Mihailescu, I.; Berthet, P.; Singh, F.; Patel, M. K.; Vincent, L. Thin Solid films 2008, 517, 916.

11. Wager, J. F. Science 2003, 300, 1245.

12. Gratzel, M. J. Photochem photobiol A 2004, 164, 3.

13. Johnson, J. C.; Yan, H.; Yang, P.; Saykally, R. J. J. Phys. Chem.. B 2003, 107, 8816.

14. Kim, I. D.; Homg, J. M.; Lee, B. H.; Kim, D. Y.; Jeon, E. K.; Choi D. K.; Yang, D. J. Appl. Phy. Lett. 2007, 91, 163109.

15. Ilican, S.; Yakuphanoglu, F.; Caglar, M.; Caglar, Y. J. Alloys and comp. 2011, 509, 5290.

16. Steinhauser, J.; fay, S.; Oliveria, N.; Vallat-sauvain E.; Ballif, C. Appl. Phys. Lett. 2007, 90, 142107.

17. Caglar, M.; Ilican, S.; Caglar, Y.; Yakuphanoglu, F. J. Alloys and Compounds 2011, 509, 3177

18. Xu, X. G.; Yang, H. L.; Wu, Y.; Zhang, D. L.; Wu, S. Z.; Miao, J.; Jiang, Y.; Qin, X. B.; Cao, X. Z.; Wang, B. Y. Appl. Phys. Lett. 2010, 97, 232502.

19. Agarwal, D. C.; Kumar, A.; Khan, S. A.; Kabiraj, D.; Singh, F.; Tripathi, A.; Pivin, J. C.; Chauhan, R. S.; Avasthi, D. K. Nucl. Instr. and Meth. B 2006, 244, 136

20. Fukuoka, O.; Matsunami, N.; Tazawa, M.; Shimura, T.; Sataka, M.; Sugai, H.; Okayasu, S. Nucl. Instr. and Meth. B 2006, 250, 295.

21. Leszek, S. Wielunski; Hill, D. H.; Quinn, J.; Bartynski, R. A.; Wu, P.; Lu, Y. Nucl. Instr. and Meth. B 2004, 219-220, 708.

22. Schwartz, K.; Volkov, A. E.; Sorokin, M. V.; Trautman, C.; Voss, K. O.; Neumann, R.; Lang, M. Phys. Rev. B, 2008, 78, 024120/1.
23. Sattonnay, G.; Lahrichi, M.; Herbst, M.; Garrido, F.; Thome, L. J. Appl. Phys. 2007, 101, 103516.

24. Ziegler, J. F.; Biersack, P.; Littmark, U. Stopping and Ranges of Ions in Matter, Pergamon, New York, 1985.

25. Szenes, G. Phys. Rev. B 1995, 51, 8026 .

26. Cullity, B. D. Elements of X-ray Diffraction, Addision-wesley, 1978, 284.

27. Agarwal, D. C.; Singh, F.; Kabiraj, D.; Sen, S.; Kulariya, P. K.; Sulania, I.; Nozaki, S.; Chauhan, R.S.; Avasthi, D. K. J. Phys. D: Appl. Phys. 2008, 41, 045305.

28. Kumaravel, R.; Gokulakrishnan, V.; Ramamurthi, K.; Sulania, Indra; Kanjilal, D.; Asokan, K.; Avasthi, D. K. Nucl. Instr. and Meth. B 2010, 268, 2391.

29. Singh, H. K.; Agarwal, D. C.; Chavhan, P. M.; Mehra, R. M.; Aggarwal, Shruti; Kumar Kulriya, Pawan; Tripathi, Ambuj; Avasthi, D. K. Nucl. Instr. and Meth. B 2010, 3223, 3226.

30. Jimenez-Gonzalez, A. E.; Urueta, J. A. S.; Suarez-Parra, R. J. Crystal Growth 1998, 192, 430.

31. Jain, Anubha; Sagar, P.; Mehra, R.M. Solid-State Electronics 2006, $50,1420$.

\section{Advanced Materials Letters}

\section{Publish your article in this journal}

ADVANCED MATERIALS Letters is an international journal published quarterly. The journal is intended to provide top-quality peer-reviewed research papers in the fascinating field of materials science particularly in the area of structure, synthesis and processing, characterization, advanced-state properties, and applications of materials. All articles are indexed on various databases including DOAJ and are available for download for free. The manuscript management system is completely electronic and has fast and fair peer-review process. The journal includes review articles, research articles, notes, letter to editor and short communications.

\section{JOURNAL}

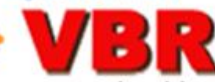

a rapid publication platform

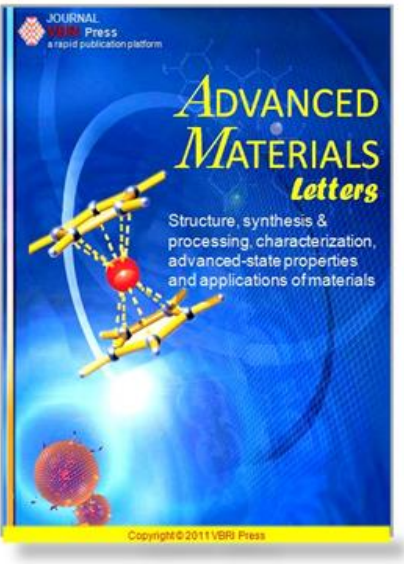

